Journal of Economics, Finance and Accounting Studies (JEFAS)

ISSN: 2709-0809

DOI: $10.32996 /$ jefas

Journal Homepage: www.al-kindipublisher.com/index.php/jefas

\title{
Financial Technology as Determinants of Bank Profitability
}

\author{
Henny Medyawati ${ }^{1} \square$ Muhamad Yunanto $^{2}$ and Ega Hegarini ${ }^{3}$ \\ ${ }^{12}$ Associate Professor, Faculty of Economics, Gunadarma University, West Java, Indonesia \\ ${ }^{3}$ Lecturer, Faculty of Computer Science and Information Technology, Gunadarma University, West Java Indonesia
}

$\square$ Corresponding Author: Henny Medyawati, E-mail: henmedya@staff.gunadarma.ac.id

\begin{tabular}{ll}
\hline ARTICLE INFORMATION ABSTRACT \\
\hline
\end{tabular}

Received: 08 September 2021

Accepted: 04 October 2021

Published: 14 October 2021

DOI: 10.32996/jefas.2021.3.2.10

\section{KEYWORDS}

ATM, FinTech, Internet banking, Mobile banking, Return On Asset (ROA)
This study analyzes the influence of financial technology on the financial performance of banks listed on the Indonesia Stock Exchange (IDX) during the 2014-2020 period. Financial technology was measured by the number of Automated Teller Machine (ATM) transactions and internet and mobile banking, while bank profitability was measured by Return On Assets (ROA). Furthermore, this study used the panel data regression analysis, with the Automated Teller Machine (ATM) transactions as well as internet and mobile banking as the independent variables, and ROA as the dependent variable. Purposive sampling was used to select six banks as samples. The results showed the fixed effect as the most suitable model, where ROA is affected by the internet and mobile banking, while the TM technology has no effect.

\section{Introduction}

The Financial Services Authority or Otoritas Jasa Keuangan (2017) defined Fin-tech as an innovation in the financial services industry that utilizes technology. Fin-tech products are a system built to conduct specific financial transaction mechanisms. In Indonesia, Fin-tech is regulated by the Bank Indonesia Regulation No. 19/12/PBI/2017 concerning Financial Technology Implementation. The regulator divides Fin-tech into payment systems, market support, investment and risk management, loans, financing and capital provision, and financial services. This study focuses on the payment system, where Fin-tech simplifies transactions using a card and an internet network. The Association of Indonesian Internet Service Providers (APJII) survey showed an annual increase in internet users in Indonesia. There were 132.7 million internet users in 2016, 143.2 million in 2017, and this increased by $64.8 \%$ to 171.17 million in 2018. Moreover, the number increased by $73.7 \%$ to 196.7 million users in the second quarter of $2019-2020$. However, the banking industry must improve its financial technology services to enable customers to make transactions from home due to the Covid-19 pandemic in 2020.

Fin-tech influences company performance in payments, clearing, and settlement systems. Although cryptocurrencies would become increasingly popular, they are unlikely to replace fiat currencies. In line with this, Kamil (2018) discussed the South Sumatra BPD, which issues e-money as financial inclusion in the region. E-money increases the use of electronic payments as a source of fee-based income. Consequently, customers are subjected to monthly administration fees and receive interest-free debt financing proportional to the e-money balance. In this case, community consumption is increased by a rise in producers' profit, affecting financial performance (Kamil, 2018).

Previous studies showed the positive and negative effects of Fin-tech on financial performance. According to Tunay, Tunay, and Akhisar (2015), internet banking positively relates to bank performance in Europe. This is because internet banking practices are superior in European countries, implying stronger bank performance. Moreover, developed countries have more sophisticated internet proponents and comprehensive technology use. Bagudu and Roslan (2017) examined 22 commercial banks in Nigeria. The results showed that mobile banking positively affects bank financial performance because customer impatience increased significantly with more prior knowledge. Also, the banking industry must adopt and use mobile banking services in its operations, seen from the increased daily use of the internet and gadgets. Sinambela and Rohani (2017) stated that internet banking does not

Copyright: (C) 2021 the Author(s). This article is an open access article distributed under the terms and conditions of the Creative Commons Attribution (CC-BY) 4.0 license (https://creativecommons.org/licenses/by/4.0/). Published by Al-Kindi Centre for Research and Development, London, United Kingdom. 
affect bank financial performance by measuring ROA and ROE. This is because banks generate higher income other than interest through internet banking services. However, this income has not covered the costs of providing internet banking services. Consequently, internet banking services have not been maximized due to the high cost of their adoption. According to Kamil (2018), electronic money positively affects LDR and GCG but negatively influences ROA, NPL, and CAR. This is because electronic money initially increased operational costs compared to its existence. Also, Abdullai (2018) stated that internet banking positively and significantly affects the operational performance of commercial banks in Nakuru. For this reason, it is recommended that commercial bank management invests in internet banking. This is due to increased efficiency, effectiveness, and productivity at commercial banks in Nakuru. In contrast, Firdaus (2019) and Rusdiono (2019) stated that Fin-tech does not affect bank financial performance. Due to the uneven distribution of Fin-tech procurement at the bank and the limited samples used, studies on this topic are limited. Furthermore, Yohani and Dita stated that the internet banking variable has no significant effect on financial performance. However, previous findings were mixed, prompting this study to be conducted.

This study was developed by Zinakova (2020) and Anugrah (2021). Zinakova (2020) examined Fin-tech, its functional mechanisms and impacts, and bank financial performance measurement. The study used profitability, liquidity, solvency, and market performance measurements. The results showed that Fin-tech affects market performance and negatively impacts profitability, liquidity, and solvency. This study measures financial performance with the same ROA approach as Anugrah's (2021), though the difference is the analytical method used. Anugrah (2021) used the multiple linear regression method, while this study uses panel data regression. Panel data helps explore economic effects that cannot be obtained using only cross-time or cross-individual data (Ekananda, 2014). Medyawati \& Yunanto (2021) also used panel data as an analytical tool to examine the banking sector. The sample in this study comprises commercial banks listed on the Indonesia Stock Exchange (IDX). Moreover, the Fin-tech measurement uses the number of ATM transactions and mobile and internet banking. Therefore, this study analyzes the effect of ATM technology, as well as internet and mobile banking, on Return of Assets (ROA). Banking financial performance was measured by profitability ratio, Return on Assets (ROA). The results are expected to contribute to management considerations for several parties, including for banks, to develop the adoption of technology-based transaction services. Additionally, the analysis is expected to contribute to science by enriching a model that analyzes the factors affecting the banks' financial performance using financial technology as an independent variable.

\section{Literature Review \\ 2.1 Transaction Cost Theory}

Oliver (2009) developed the theory of transaction to analyze the impact of electronic banking on the performance of commercial banking companies registered in Kenya. Technology is adopted to lower the customers' and banking transaction costs and increase profits and income (Ogutu \& Fatoki, 2019).

\subsection{Technology Acceptance Theory}

Venkatesh and Davis (2000) stated that ease of technology use indicates implementing and learning new information systems. This model emphasizes the ease of using new technology, affecting its perceived usefulness. External variables, such as environmental factors, influence perceptions of usefulness and utility. Therefore, technology acceptance theory relies on perceived usefulness and ease of use and is widely applied in studies on information technology. Liu and Arnett (2000) analyzed the important variables to produce a successful website based on the technology acceptance theory. Therefore, this fundamental theory supports the present study on the effect of electronic banking on the performance of banks registered in Kenya (Ogutu \& Fatoki, 2019).

\subsection{Unified Theory of Acceptance and Use of Technology (UTAUT)}

This theory was first proposed by Venkatesh and Davis (2000), which examined eight models on information and communication technology (ICT). The models include technology acceptance, social cognitive theory, planned behavior, diffusion of innovation, computer use, motivation model, rational action, and planned behavior theory. The theory of acceptance uniformity and technology uses was created to assist in adopting and disseminating information systems. Venkatesh and Davis (2000) identified four main ideas in the UTAUT theory, including effort expectations, performance expectations, enabling conditions, and social influence. These four ideas positively impact IT or information systems' behavioral intentions and eventual behavior (Venkatesh \& Davis, 2000). UTAUT discusses the adoption and use of innovative technologies by bank employees and customers. This model addresses user intentions for ICT adoption and successful user behavior. Furthermore, UTAUT provides managers with decisionmaking tools to understand new technologies and predict user behavior in receiving information technology (Ogutu \& Fatoki, 2019).

Fin-tech is the abbreviation of financial technology interpreted as a combination of technology and financial services (www.bi.go.id). Hsueh and Kuo (2017) stated that financial technology could be referred to as Fin-tech, a new financial service 
model developed with IT innovation. Also, Dorfleitner, Hornuf, Schmitt, and Weber (2017) defined Fintech as a fast-moving industry with many different business models. It is an innovation that refers to modern technology to introduce practicality to facilitate access, convenience, and more economical costs (Ansori, 2019). Automated Teller Machines (ATMs) (Otoritas Jasa Keuangan, 2017) are terminals or computers connected to the bank's communication network. They allow customers to conduct financial transactions independently without assistance from tellers or other bank staff. Technological developments have enabled banks to introduce ATMs that serve non-cash transactions, cash deposit transactions, and non-cash and cash deposit transactions.

\subsection{Mobile Banking and Internet Banking Technology}

Internet banking is a service for conducting banking transactions via the Internet (Otoritas Jasa Keuangan, 2017). It involves using internet technology to conduct transactions and obtain other information through the bank's website. Therefore, the internet is a medium of contact between customers and the bank without visiting the bank office. The customer uses a desktop computer, laptop, tablet, or smartphone connected to the internet to link their machine and the bank system. In comparison, mobile banking allows bank customers to transact via gadgets or smartphones. This technology uses the menus available on the Subscriber Identity Module (SIM), Supplementary Unstructured Service Data (USSD), or applications downloaded and installed by customers (Otoritas Jasa Keuangan, 2017). Mobile banking features include three types or groups of information services. The first group comprises balance, account mutation, credit card billing services, interest rates, and the nearest branch or ATM location. The second group consists of transaction services, such as transfers, bill payments, including electricity, water, taxes, credit cards, insurance, and the Internet. The third group of information services comprises purchases, such as ticket balance. Harelimana (2018) analyzed the impact of mobile banking on the financial performance of Unguka Microfinance Bank Ltd in Rwanda. The findings showed that Unguka Bank Ltd offered mobile banking services such as fund transfer between accounts, bill payment, order for checkbooks and bank statements, and mobile money. These mobile banking products increased Unguka Ltd's revenue in the last three years. Additionally, Karsh and Abufara (2020) analyzed the internet and mobile banking effect on net profit, ROA, and ROE. The results showed that the two independent variables did not affect the financial performance variable.

\subsection{Profitability as a Bank Performance Indicator}

Profitability is a suitable indicator to measure company performance (Masdupi \& Defri, 2012). In this study, the chosen company's performance measure is Return on Assets (ROA), a ratio showing the return on the company's total assets. Moreover, ROA measures the company's profitability better because it shows the management's effective use of assets to earn income (Kasmir, 2012). The bank's performance in generating profits is calculated as the profit before tax on the average of total assets. In this case, a higher ROA percentage implies better use of assets and increased profits (Kamil, 2018). Other studies that used ROA as the dependent variable are Karsh and Abufara (2020), Zinakova (2020), Yohani and Dita (2019), Harelimana (2018), Sinambela and Rohani (2017), Margaretha (2015), Rauf, Qiang, and Mehmood (2014), Egan and Prawoto (2013), and Maholtra and Singh (2009).

\subsection{The Effect of Fin-tech on Financial Performance}

Karsh and Abufara (2020) showed that financial technology does not affect the banking sector's profitability. This first model used in this study analyzes mobile penetration, a country's digital technology availability, and the number of new Fin-tech companies as the independent variable. The second model analyzes a bank's financial performance measured by net interest margin, Return on Equity (ROE), and ROA. The independent variables are services and products, technology, platform delivery, convenience to customers, and lower operating cost. Sudaryanti, Sahroni, and Kurniawati (2018) stated that mobile banking does not affect banking performance. Conversely, Abdullai (2018) stated that internet banking positively affects the operational performance of commercial banks in Nakuru. Therefore, it is recommended that commercial bank management invests in internet banking to increase efficiency, effectiveness, and productivity, as seen at the commercial banks in Nakuru. Moreover, Bagudu and Roslan (2017) found a positive influence of mobile banking on the performance of commercial banks in Nigeria. This was indicated by the customer's impatience that significantly increased with more prior knowledge. Therefore, Bagudu and Roslan (2017) stated that the banking industry must still adopt and use mobile banking services, though there was an increase in the daily use of the internet and gadgets. Furthermore, Tunay et al. (2015) found a positive relationship between internet banking and bank performance in Europe. Internet banking in European countries is superior, resulting in high bank performance. This is because developed countries have more sophisticated internet proponents and comprehensive technology use. Margaretha (2015) analyzed the impact of electronic banking on bank performance measured by ROA and ROE. The results showed that internet banking affected the performance of commercial banks. Moreover, Dinh (2015) evaluated the impact of internet banking on profitability ratios, noninterest operating expenses, and incomes of banks in Vietnam from 2009 to 2014. The study used random effect (REM) and fixed effect (FEM) models to determine the relationships between Internet banking indicators and bank performance. The regression model results showed that internet banking influenced profitability by increasing income from service activities. However, the impact was insignificant with a lag time of over 3 years, longer than previous findings.

Rauf, Qiang, and Mehmood (2014) analyzed the relationship between internet banking and the performance of the Pakistan banking sector. The ROA and ROE variables were explored using regression analysis on financial data collected quarterly from the 
State Bank of Pakistan (SBP) from 2004 to 2013. This model used other variables, such as the distribution of credit risk, weighted average interest rate, Non-Performance Loan (NPL) to the total down payment, intermediary costs, and operating performance. The aim was to expand the study area to the bank's internal factors affecting profitability. Moreover, non-financial factors, such as customer satisfaction, speed, and efficiency, were controlled in the model. Ordinary least squares results showed that internet banking positively and significantly impacted the profitability of Pakistan's banking sector between 2004 and 2013 . Egan and Prawoto (2011) analyzed the effect of internet banking on banks' earning performance. The previous analysis and discussion show that internet banking negatively and significantly affects public bank earnings in Indonesia based on financial statements from 2002 to 2011. Maholtra dan Singh (2009) examined the impact of internet banking on bank performance and risk in India. The univariate analysis results showed that internet banks are larger with operating efficiency ratios and profitability compared to nonInternet banks. Also, internet banks rely more on core deposits for funding than non-Internet banks. However, the multiple regression results show that the profitability and offering of Internet banking do not have a significant association. In contrast, internet banking significantly and negatively associates with the banks' risk profile. From the previous findings, the hypothesis in this study is that ATM technology, internet banking, and mobile banking affect ROA.

\section{Method}

This study was conducted on conventional and Islamic commercial banks listed on the Indonesia Stock Exchange from 2014 to 2020. The sample banks were selected starting from 2014, the year when companies began developing Fin-tech. The study population comprised 44 commercial banks registered with the Financial Services Authority (Otoritas Jasa Keuangan). They were selected from 2014 to 2020 using the purposive sampling technique. Six banks were selected as samples based on certain criteria. They had commercial banks listed on the Indonesia Stock Exchange, with annual reports published on the website www.idx.co.id (2014-2020). Furthermore, the banks had to be users of ATM technology, as well as internet and mobile banking, and had published data on the use of these services in the 2014-2020 period. Of the 44 commercial banks listed on the IDX, 26 had not published annual financial reports in 2014-2020. Furthermore, four commercial banks did not utilize ATM technology and internet and mobile banking together. Furthermore, eight commercial banks did not use ATM technology, as well as mobile and internet banking in the 2014-2020 period. The six banks that passed the criteria are PT. Bank Central Asia, Tbk., PT. Bank Negara Indonesia (Persero) Tbk., PT. Bank Rakyat Indonesia (Persero), Tbk., PT. Bank Tabungan Negara (Persero), Tbk., PT. Bank CIMB Niaga, Tbk., and PT. Bank Mega, Tbk. The study was conducted for seven years, resulting in 42 observations by multiplying samples by study years. Data were obtained from annual financial and sustainability reports from the www.idx.co.id page and the banks' official pages. The dependent variable is financial performance measured by Return on Assets (ROA). The independent variable is the use of financial banking technology represented by the number of ATMs, as well as internet and mobile banking transactions. The study used the following equation:

$$
\operatorname{ROA}_{i t}=\beta_{0}+\beta_{1} A T M+\beta_{2} \text { Mobile }+\beta_{3} \text { lbank }
$$

Data were analyzed using panel data regression, whose procedure is described in Figure 1. The first step is to generate three possible effect models, including common effect, fixed effect, and random effect models. This is followed by the Chow Test to determine the most appropriate effect model between common effect and fixed-effect models. When the fixed effect model is selected as the most appropriate, the Hausman test is performed to determine the suitable model between the fixed and random effect models. However, when the common effect model is selected, the Lagrange Multiplier Test is performed to determine the most appropriate between the random and common effect models.

\begin{tabular}{|c|c|c|c|c|c|c|}
\hline \multicolumn{7}{|c|}{ ESTIMATION MODEL DETERMINATION } \\
\hline \multicolumn{3}{|c|}{ COMMON EFFECT MODEL } & FIXED EF & ECTMODEL. & \multicolumn{2}{|c|}{ RANDOM EFFECT MODEL } \\
\hline \multicolumn{7}{|c|}{ ESTIMATION METHOD DETERMINATION } \\
\hline \multicolumn{3}{|c|}{ CHOW TEST } & LAGRANGE & IULTIPLIERTEST & & HAUSMAN TEST \\
\hline \multicolumn{7}{|c|}{ CLASSICAL ASSUMPTION AND GOODNESS-FIT MODEL.TESTS } \\
\hline \multicolumn{2}{|c|}{ NORMALITY } & \multicolumn{2}{|c|}{ MULTICOLINEARITY } & \multicolumn{2}{|c|}{ HETEROSEEDASTICITY } & AUTOCORRELATION \\
\hline \multicolumn{7}{|c|}{ INTERPRETING RESULTS } \\
\hline R SQUARE & ANOV: & (F-TEST) & TTEST & GOODNESS OF F & & REGRESSIONEQUATION \\
\hline
\end{tabular}

Figure 1. Panel Data Regression Analysis Procedures (Adapted from Zulfikar, 2018) 
A classical assumption test is used to check for normality, multicollinearity, autocorrelation, and heteroscedasticity in the regression model. A linear regression model is considered good when the residual data is normally distributed without multicollinearity, heteroscedasticity, and autocorrelation. Figure 1 shows that the appropriate model was determined in the early stages of data processing. However, before panel data regression, the classical assumption test was performed to check for heteroscedasticity. Moreover, the fixed-effect model is estimated by weighting the cross-section in case there is heteroscedasticity. The last step is to interpret the resulting model from the common, fixed, and random effect models.

\section{Result and Discussion}

\subsection{Descriptive Statistics}

This study was conducted on the banks listed on the Indonesia Stock Exchange in 2014-2020, using six banking entities as samples. The highest ROA from 2014 to 2020 was 26.9, achieved by Bank BCA. The highest number of ATM transactions was 17,194.59 million by Bank BRI. Furthermore, the highest number of internet and mobile banking transactions was 14.346 million and 15,138.7 million, respectively, by Bank BCA.

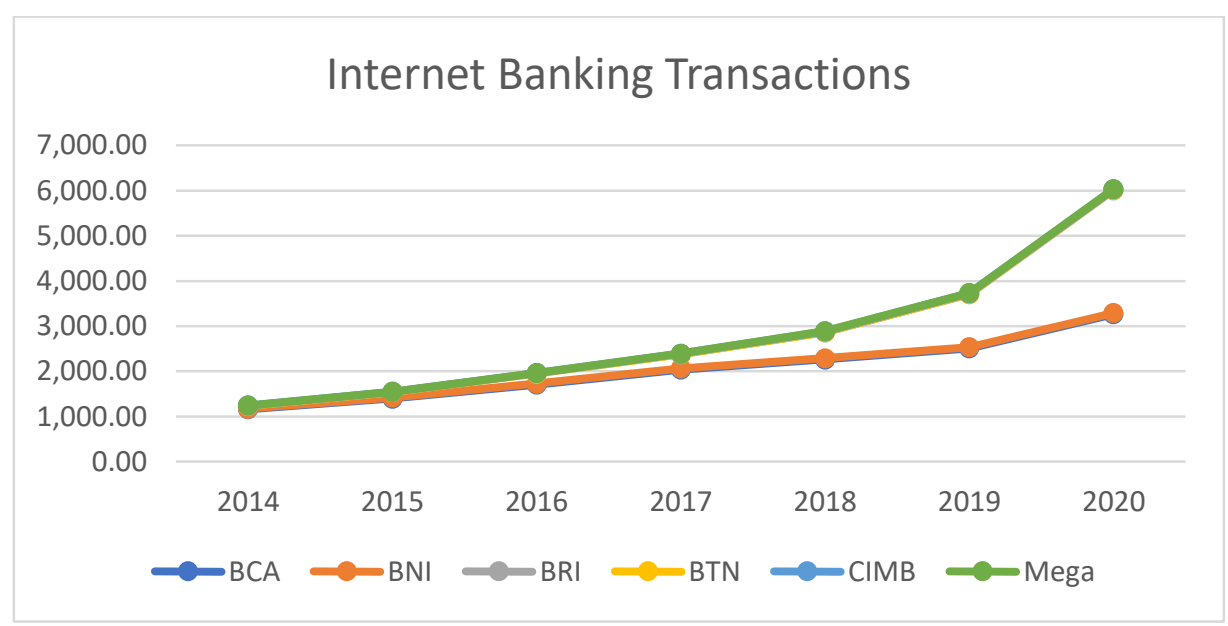

Figure 2. Internet Banking Transaction Growth Chart (in million of rupiah) for period 2014-2020

During the study period, the number of internet banking technology users had a mean of 471,9683 or a total of $471,968,300$ transactions. Figure 2 shows that the lowest mean of internet banking transactions was 0.20, or a total of 200,091 at PT. State Savings Bank (Persero) Tbk. in 2014. This is the lowest amount compared to other internet banking transactions in this study. It shows that many BTN customers do not conduct internet banking financial transactions but prefer ATMs. Furthermore, the highest mean of internet banking transactions was 32640.0, or 3,264,000,000 at PT. Bank Central Asia Tbk. in 2020. This shows that many $\mathrm{BCA}$ customers trust internet banking services in conducting banking financial transactions. The convenience offered by BCA makes customers use internet banking services.

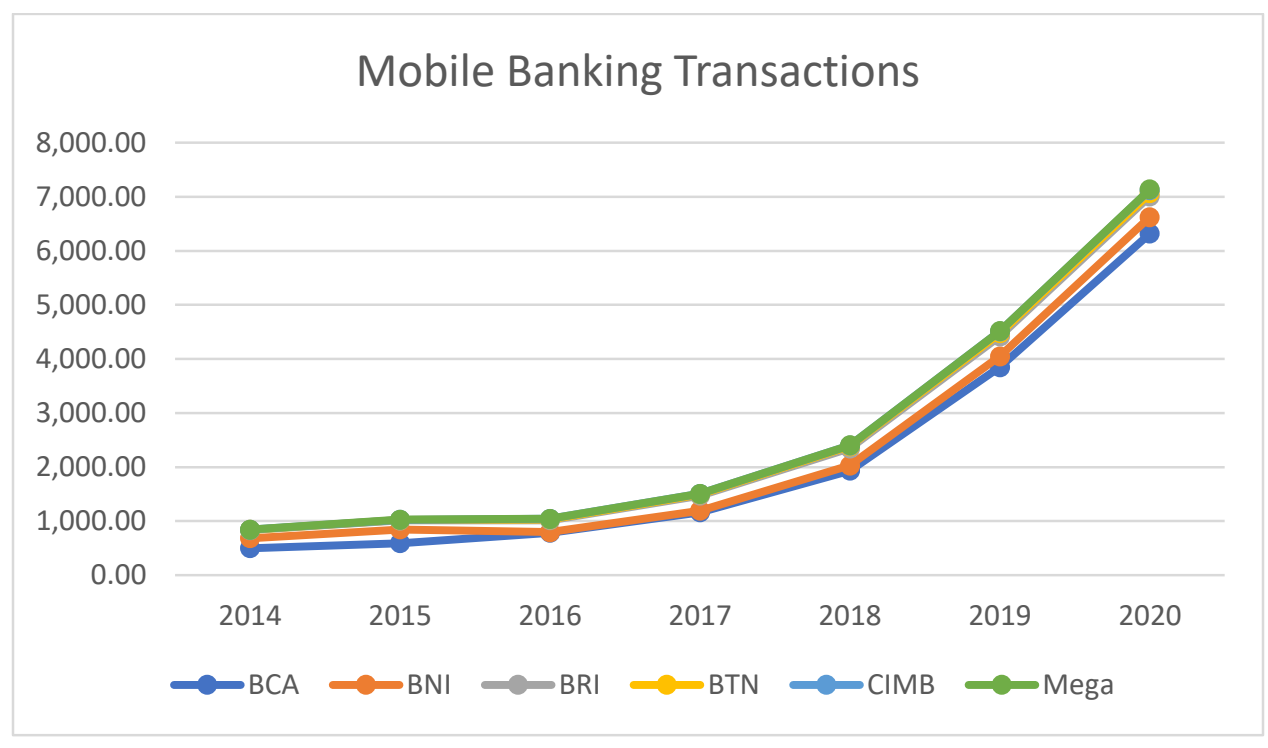


Figure 3. Mobile Transaction Chart (in a million rupiah) period 2014-2020

The use of mobile banking technology during the study period has a mean of 416,010,200 transactions. Figure 3 shows that the lowest mean of mobile banking transactions was 0.56 , or a total of 560,000 at PT. Bank Mega Tbk. in 2014. It is the lowest amount compared to other mobile banking transactions. This is because Bank Mega launched mobile banking services known as Mega Mobile in 2014. Therefore, few customers enjoy these services, making the number of mobile banking transactions low. Also, the highest mean of mobile banking transactions was 6321.00 , or a total of 6,321,000,000 at PT. Bank Central Asia Tbk. in 2020. This shows that BCA customers have more confidence in mobile banking services for financial transactions. Additionally, this is supported by the number of BCA customers that have experienced the convenience of the BCA mobile banking service. As a result, they are more comfortable transacting using this service. The use of mobile banking increased rapidly to $83 \%$ during the Covid19 pandemic, while ATMs decreased to 34\%. This was shown by the Jenius Study survey involving 567 respondents aged $26-40$ to determine the financial condition of the digital-savvy community (Anggraeni, 2021).

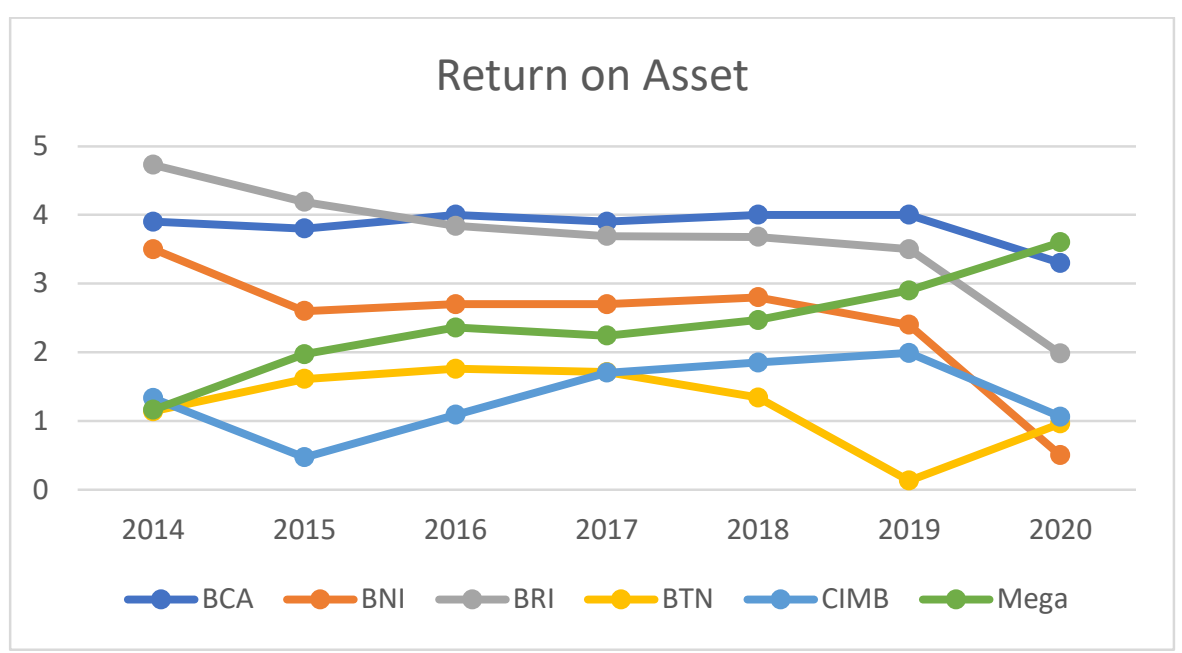

Figure 4. Graph of ROA Movement for the 2014-2020 period

The average value of the ROA variable was 2.4893 or $2.4893 \%$ during the study period. The highest ROA from the six bank samples was $4.73 \%$ obtained by PT. Bank Rakyat Indonesia (Persero) Tbk. in 2014. In contrast, the lowest ROA was $0.13 \%$ produced by PT. State Savings Bank (Persero) Tbk. in 2019. The complete ROA movement from 2014 to 2020 is shown in Figure 4. Therefore, higher ROA improves the company's management of assets to generate profits and vice versa.

The average number of ATM transactions during the study period was 901,023,100. The lowest mean of ATM transactions was 18.60 or a total of $18.600,000$ at PT. Bank Mega Tbk. in 2020. This is the lowest amount compared to the number of other banking ATM transactions in this study. It shows that Bank Mega and its customers have not maximized the ATM technology in financial banking transactions because ATMs are unevenly distributed in Indonesia. In contrast, the highest mean of ATM transactions was 3745.59 or a total of 3,745,590,000 at PT. Bank Rakyat Indonesia (Persero) Tbk. in 2020. This shows BRI's convenience in serving customers through its ATMs spread across Indonesia. As a result, customers use ATMs in conducting banking financial transactions. Figure 5 shows the increase in ATM transactions. 


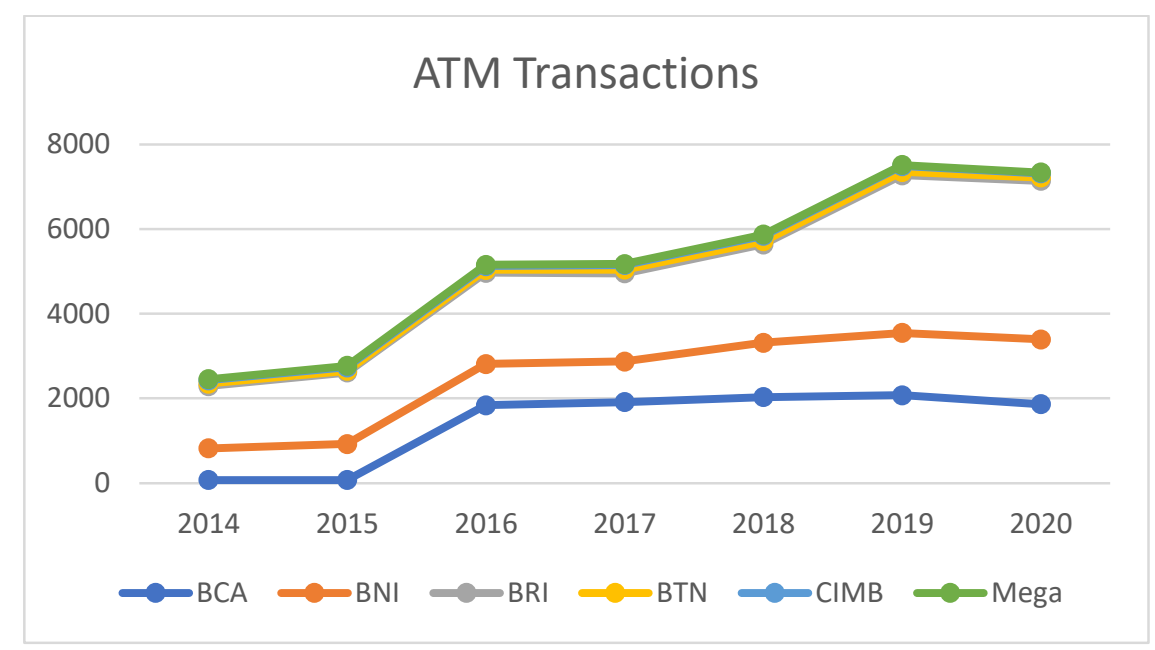

Figure 5. ATM Transaction Growth Chart in 2014-2020 period

The classical assumption test was first performed to check for normality, multicollinearity, autocorrelation, and heteroscedasticity in the regression model. The test results showed that the data were normally distributed with no multicollinearity and autocorrelation, though there was heteroscedasticity. This condition is evaluated using panel data estimates with the cross-section weights procedure (Ekananda, 2014; Prasanti, Wuryandari, Rusgiyono, 2015).

\subsection{Panel Data Regression Analysis}

The common, fixed, and random effect model estimation results are displayed in Tables 4, 5, and 6, followed by their related regression equations

Table 4. Common Effect Model

\begin{tabular}{lcl}
\hline Variables & \multicolumn{1}{c}{ Coefficient } & Probability \\
\hline ATM transaction & 0.001411 & 0.0000 \\
Mobile transaction & 0.000257 & 0.0550 \\
lbank transaction & 0.000036 & 0.9568 \\
\hline R-squared & 0.278 & \\
& \\
ROA $=0.001411$ ATM +0.000257 Mobile +0.000036 lbank
\end{tabular}

The estimation results using the common effect model (CEM) show that ROA is affected by ATM transactions, with $27.8 \%$ as the coefficient of determination. The classical assumption test showed the presence of heteroscedasticity. Therefore, the fixed-effect model was estimated by weighting the cross-section, obtaining the results in Table 5.

Table 5. Fixed Effect Model

\begin{tabular}{lcc}
\hline Variables & Coefficient & Probability \\
\hline Constant & 2.704624 & 0.0000 \\
ATM & 0.000200 & 0.0000 \\
Mobile & 0.000173 & 0.5415 \\
lbank & -0.000983 & 0.0117 \\
\hline R-squared & 0.885 & \\
\multicolumn{2}{c}{ ROA $=2.704624+0.000200 \mathrm{ATM}+0.000173$ Mobile -0.000983 Ibank }
\end{tabular}

A Chow test was performed to select the most suitable model. The results showed the probability value of cross-section $\mathrm{F}$, with a Chi-Square value of 0.0000 , less than 0.05 , meaning that the fixed effect model is the most appropriate.

Table 6. Random Effect Model 


\begin{tabular}{lcc}
\hline Variables & Probability \\
& Coefficient & \\
\hline Constant & 2.397033 & 0.0000 \\
ATM & 0.000119 & 0.6650 \\
Mobile & 0.000167 & 0.3027 \\
lbank & -0.000177 & 0.6221 \\
\hline
\end{tabular}

R-squared $\quad 0.1421$

The random-effect model was then estimated, obtaining the results shown in Table 5. The equation obtained by the random effect model estimation is:

$$
\mathrm{ROA}=2.397033+0.000119 \mathrm{ATM}+0.000167 \text { Mobile }-0.000177 \mathrm{lbank}
$$

A Hausmann test was performed to select the most suitable model, resulting in the probability value of a random cross-section as 0.0002 , less than 0.05 . Therefore, the fixed-effect model is the most appropriate, as shown in equation (2).

The classical assumption normality test using the One-Sample Kolmogorov-Smirnov method shows a significance of $0.200>0.050$, meaning that the data in the study were normally distributed. The VIF results of the three independent variables showed a value smaller than 10. Furthermore, the data processing results show a 0.547 tolerance ratio for ATM transactions, 0.241 for internet banking transactions, and 0.352 for mobile banking transactions. This indicates that the tolerance ratios for independent variables are greater than 0.1. Moreover, the VIF values of ATM, internet banking, and mobile banking transactions are 1.827, 4.141, and 2.839, respectively, implying no multicollinearity. The autocorrelation test used the Durbin-Watson method, obtaining a value of 1.107. This indicates that the regression model has no autocorrelation disorders because the resulting values range between -2 and 2 (-2 1.107 2). The scatter plot results show that these points form patterns, implying heteroscedasticity. Therefore, an estimation procedure was conducted in line with this condition.

\subsection{Impact of ATM Transaction, Mobile Transaction, and Mobile Banking Transaction: Fixed Effect Model}

The F-test results show a probability of 0.000 , meaning that the variable under study is feasible to analyze the factors affecting ROA. Therefore, the use of ATMs and internet and mobile banking affects ROA or the banking sector's profitability. These results support Ogutu and Fatoki (2019), which stated that online banking positively influences the financial performance of banks listed on the Nairobi Securities Exchange (NSE). Furthermore, the use of FinTech in the banking sector improves customer service and reduces operational costs for existing bank branches. Banking and financial transactions become easier, faster, and more efficient using financial technology, increasing the bank's profits. Therefore, more transactions using FinTech increase ROA.

The data processing results showed that the fixed effect model using a cross-section weights procedure was the most appropriate. Table 5 shows that internet and mobile banking transactions affect bank profitability as measured by ROA. Also, the negative coefficient for the internet banking variable implies its indirect relationship with bank profitability.

The use of Fin-Tech proxied by internet and mobile banking transactions affects financial performance, as indicated by the level of ROA in the six banks during the 2014-2020 period. Also, the impact of internet banking technology on ROA was felt by bank customers. This study used data up to 2020 because of the COVID-19 pandemic conditions in Indonesia in March 2020. Therefore, internet banking became the right choice to reduce physical contact between customers and bank employees. However, other customers cannot maximally apply internet banking because they are unfamiliar with the system. Also, there are concerns about personal data leakage or loss of money (Sudarsono, 2021). These results support Maholtra and Singh (2009), Egan and Prawoto (2013), and Rauf et al. (2014), which showed that internet banking affects bank performance. However, the results contradict Sudaryanti, Sahroni, and Kurniawati (2019), which stated that mobile banking does not affect bank performance (ROA).

The data processing results indicate that ATM transactions do not affect financial performance. The results may not be generalized since the study was conducted up to 2020 due to the COVID-19 pandemic. Transactions using ATMs, debit, and credit cards decreased by $18.9 \%$ during the pandemic. According to Perry Warjiyo, the Governor of Bank Indonesia, digital services are increasingly in demand during the pandemic. The limitations of human mobility make digital financial transactions the best choice (Whulandari \& Zuraya, 2020). However, these results contradict Anugrah (2021) and Ogutu and Fatoki (2019), which stated that ATM transactions affect bank financial performance.

\section{Conclusion}

This study analyzes the effect of ATM technology, as well as internet and mobile banking, on Return of Assets (ROA). ATM technology does not affect ROA, which is influenced by the internet and mobile banking. However, ATM technology, as well as internet and mobile banking, simultaneously affect ROA. The results show that fintech affects bank performance, one of the 
indicators is profitability. The findings of this study reaffirm that mobile banking and internet banking affect bank profitability so that these findings are expected to contribute to science by enriching a model that analyzes the factors affecting the banks' financial performance using financial technology as an independent variable. The limitation of this research is that it has not used all the variables that can be used as a measure of Fin-tech, for example, electronic money (e-money). This study was conducted during the Covid-19 pandemic, which affected data collection. According to Bank Indonesia, digital services for financial transactions increased starting in 2020. Therefore, banks should improve the quality of digital services, especially internet and mobile banking. Suggestions for future studies, that the studies should add other Fin-tech variables believed to affect ROA, such as e-wallet, e-money, and SMS banking.

Acknowledgment: Thank you to colleagues who have been willing to provide comments or input for this research

Funding: This research received no external funding

Conflict of interest: the authors declare no conflict of interest

\section{References}

[1] Abdullai, H. (2018). Effect of internet banking on the operational performance of commercial banks in Nakuru County, Kenya. International Journal of Economics, Finance and Management Sciences, 6(2), 60. doi.org/10.11648/j.jiefm.20180602.14.

[2] Anggraeni, R. (2021). Selama pandemi penggunaan mobile banking tembus $83 \%$. Retrieved from: https://www.inews.id/finance/keuangan/selama-pandemi-penggunaan-mobile-banking-tembus-83-persen.

[3] Ansori, M. (2019). Perkembangan dan dampak financial technology (fintech) terhadap industri keuangan syariah di Jawa Tengah. Wahana Studi Keislaman, 5(1), 31-45.

[4] Bagudu, K., \& Roslan. (2017). The effect of mobile banking on the performance of commercial banks in Nigeria. International Research Journal of Management, IT \& Social Sciences, 4(2), 74-80. doi.org/10.21744/irjmis.v4i2.392

[5] Dinh, V., Le, U., \& Le, P. (2015). Measuring the impacts of internet banking on bank performance: Evidence from Vietnam. Journal of Internet Banking and Commerce, 20(2), 103. doi.org/10.4172/1204-5357.1000103

[6] Dorfleitner, G., Hornuf, L., Schmitt, M., Weber, M., Dorfleitner, G., Hornuf, L., Schmitt, M., \& Weber, M. (2017). Definition of FinTech and Description of the FinTech Industry. FinTech in Germany, 2(37), 5-10. doi.org/10.1007/978-3-319-54666-7_2

[7] Egan, R., \& Prawoto, H. (2013). Pengaruh internet banking terhadap kinerja perbankan di Indonesia (Studi empiris pada bank yang listing di BEI). Jurnal Akuntansi Bisnis, 11(22), 1689-1699.

[8] Ekananda, M. (2014). Analisis ekonometrika data panel, bagi penelitian ekonomi, manajemen dan akuntansi. Jakarta: Mitra Wacana Media.

[9] Harelimana, J. B. (2018). Impact of mobile banking on the financial performance of Unguka Microfinance Bank Ltd, Rwanda. Journal of Harmonized Research in Management, 4(1), 26. doi.org/10.30876/johr.4.1.2018.26-40

[10] Hsueh, S. C., \& Kuo, C. H. (2017). Effective matching for P2P lending by mining strong association rules. ACM International Conference Proceeding Series, Part F1309(1), 30-33. doi.org/10.1145/3133811.3133823

[11] Kamil, I. (2018). Pengaruh Peraturan Bank Indonesia Nomor 18/17/PBI/2016 Tentang Uang Elektronik terhadap Kesehatan Bank Pemerintah Daerah (Studi pada PT. Bank Pembangunan Daerah Sumatera Selatan dan Bangka Belitung) (Undergraduate's thesis). Fakultas Ekonomi, Universitas Islam Negeri Maulana Malik Ibrahim Malang.

[12] Kasmir. (2018). Analisis laporan keuangan (edisi revisi 2018). Jakarta: Rajawali Pers.

[13] Liu, C. \& Arnett, K. P. (2000). Exploring the factors associated with website success in the context of electronic commerce. Information \& Management, 38(1), 23- 33.

[14] Maholtra, J. \& Singh, B. (2009). The impact of internet banking on bank performance and risk: The Indian experience. Eurasian Journal of Business and Economics, 2(4), 43-62.

[15] Margaretha, F. (2015). Dampak electronic banking terhadap kinerja perbankan Indonesia. Jurnal Keuangan dan Perbankan, 19(3), 514-524.

[16] Masdupi, E. \& Defri. (2010). Pengaruh Capital Adequacy Ratio (CAR), likuiditas dan efisiensi operasional terhadap profitabilitas perusahaan perbankan yang terdaftar di BEI. Jurnal Kajian Manajemen Bisnis, 1(1), 1-18.

[17] Medyawati, H., \& Yunanto, M. (2021). Determining firm value in the Indonesian banking sub-sector. Economics and Business Quarterly Reviews, 4(2), 68-78.

[18] Ogutu, M., \& Fatoki, O. (2019). Effect of e-banking on the financial performance of listed commercial banks In Kenya. Global Scientific Journal, 7(1), 722-738.

[19] Otoritas Jasa Keuangan. (2015). Bijak Ber-eBanking. Jakarta: Otoritas Jasa Keuangan.

[20] Peraturan Bank Indonesia. 2016. PBI No 18/17/PBI/2016 tentang Uang Elektronik.

[21] Prasanti, T.A., Wuryandari, T., \& Rusgiyono, A. (2015). Aplikasi regresi data panel untuk pemodelan tingkat pengangguran terbuka Kabupaten/Kota di Provinsi Jawa Tengah. Jurnal Gaussian, 4(3), 687-696.

[22] Rauf, S., Qiang, F., \& Mehmood, R. (2014). Internet banking as a determinant of Pakistan banking sector profitability: ROA \& ROE model. European Journal of Business and Management, 6(1), 107-114.

[23] Rusdiono k. (2019). Analisis perbedaan rasio profitabilitas perbankan (ROA) sebelum dan sesudah mengadopsi internet banking terhadap perbankan yang terdaftar di Bursa Efek Indonesia (BEI). ZhafiR Journal of Islamic Economics, Finance and Banking, 1(1), 25-38.

[24] Sinambela, E., \& Rohani. (2017). Pengaruh penyediaan layanan internet banking terhadap kinerja keuangan perbankan di Bursa Efek Indonesia. Forum Keuangan Dan Bisnis Indonesia, 6(1), 87-94.

[25] Sudarsono, H. (2021). Dampak pandemi covid-19 terhadap penggunaan internet banking. Retrieved from https://fecon.uii.ac.id/blog/2021/01/30/dampak-pandemi-covid-19-terhadap-pengunaan-internet-banking/

[26] Sudaryanti, D. S., Sahroni, N., \& Kurniawati, A. (2018). Analisa pengaruh mobile banking terhadap kinerja perusahaan sektor perbankan yang 
tercatat di Bursa Efek. Jurnal Ekonomi Manajemen, 4(2), 96-107.

[27] Tunay, K. B., Tunay, N., \& Akhisar, İ. (2015). Interaction between internet banking and bank performance: The Case of Europe. Procedia Social and Behavioral Sciences, 195(1), 363-368 https://doi.org/10.1016/j.sbspro.2015.06.335

[28] Venkatesh, V. \& Davis, F.D. (2000). A theoretical extension of the technology acceptance model: Four longitudinal field studies. Management Science, 46(2), 186-204.

[29] Yohani, \& Dita, F. I. (2019). Pengaruh Internet Banking terhadap Kinerja Keuangan pada Bank Umum Konvensional yang terdaftar di Bursa Efek Indonesia (Periode 2015 - 2018). Foreign Affairs, 91(5), 11. doi.org/10.1017/CBO9781107415324.004

[30] Zinakova, T. (2020). Financial technology (FinTech) and the performance of commercial banks in Nordic countries. March, 1(1), 124 https://www.theseus.fi/handle/10024/340865

[31] Whulandari, R. \& Zuraya, N. (2020, September 29). BI: Transaksi ATM dan kartu debit turun selama pandemi. Retrieved from https://www.republika.co.id/berita/qhenzm383/bi-transaksi-atm-dan-kartu-debit-turun-selama-pandemi 